\title{
PENGEMBANGAN VIDEO PEMBELAJARAN MATEMATIKA BERORIENTASI KEBUDAYAAN LOKAL PADA SEKOLAH DASAR
}

\author{
Yosua Damas Sadewo $\circledast^{1)}$, dan Pebria Dheni Purnasari $\varpi^{2)}$ \\ ${ }^{1}$ Teknologi Pendidikan, Universitas Negeri Jakarta \\ ${ }^{2}$ Pendidikan Guru Sekolah Dasar, Institut Shanti Bhuana \\ ${ }^{1}$ J1. R.Mangun Muka Raya No.1, Rawamangun, Kota Jakarta Timur, 13220 \\ ${ }^{2}$ Jl. Bukit Karmel No.1, Sebopet, Bengkayang Kalimantan Barat, 79211 \\ E-mail : yosuadamassadewo_9902921035@mhs.unj.ac.id ${ }^{1)}$, pebria.dheni@ shantibhuana.ac.id ${ }^{2)}$
}

\begin{abstract}
ABSTRAK
Fokus Penelitian dalam penelitian pengembangan ini adalah menghasilkan produk Video Pembelajaran Matematika Berorientasi Kebudayaan Lokal yang sesuai kebutuhan dan mempunyai karakteristik yang praktis yang dapat dengan mudah digunakan oleh guru dan siswa SDN 02 Bengkayang. Penelitian ini dikategorikan dalam jenis penelitian pengembangan (research and development), yaitu pengembangan Video Pembelajaran Matematika Berorientasi Kebudayaan Lokal yang berorientasi pada model pengembangan Borg and Gall dan ADDIE. Lokasi penelitian ini adalah SDN 2 Bengkayang dengan subjek penelitian siswa kelas 1 SDN 2 Bengkayang, beserta guru kelas, dan orang tua siswa. Instrumen yang digunakan terdiri dari lembar observasi, lembar uji pakar, catatan penelitian, dan dokumentasi. Teknik analisis data dalam penelitian ini menggunakan teknik kuantitatif deskriptif yakni dengan menganalisis hasil uji pakar, dan lembar observasi. Hasil dalam penelitian ini adalah secara garis besar video pembelajaran yang dikembangkan telah berada pada kategori valid dan layak untuk diimplementasikan. Hal ini ditunjukkan dengan hasil penilaian uji pakar yang mendapat nilai rata-rata 41,67 di mana kategori dari nilai tersebut adalah baik. Pengukuran karakteristik video dilakukan dengan menggunakan lembar observasi dengan nilai rata-rata sebesar 77,2 dengan kategori baik. Persentase dari penilaian lembar observasi menunjukkan nilai sebesar $46,43 \%$ siswa memberikan respond yang sangat baik, $17,86 \%$ siswa memberikan respond yang baik, dan 35,71\% siswa memberikan respond cukup. Hasil ini mengindikasikan bahwa video pembelajaran yang dikembangkan memiliki karakteristik yakni mudah dipahami siswa, menarik minat dan antusiasme siswa dalam pembelajaran, serta dapat membantu siswa saat belajar di rumah.
\end{abstract}

Kata Kunci: Media Pembelajaran, Video Pembelajaran, Kebudayaan Lokal, Matematika, Sekolah Dasar

\section{PENDAHULUAN}

Istilah Study from Home atau belajar dari rumah menjadi sapaan yang seringkali terdengar dalam dunia pendidikan semenjak pandemi Covid-19 melanda. Pola pembelajaran yang berubah dari tatap muka secara langsung menjadi tatap muka secara virtual merupakan bagian dari proses belajar dari rumah atau study from home. Belajar dari rumah merupakan kebijakan yang diberlakukan guna mengurangi penularan wabah virus covid-19. Hal tersebut merupakan sebuah kebijakan yang dikeluarkan oleh Presiden Republik Indonesia, Bapak Joko Widodo pada tahun 2020, yakni pada tanggal 16 Maret 2020 beliau menegaskan bahwa kebijakan untuk beraktivitas produktif di rumah perlu dilakukan untuk menekan penyebaran virus covid-19. Presiden Joko Widodo juga menyampaikan mengenai kebijakan belajar dari rumah, bekerja dari rumah, dan ibadah di rumah perlu menggencarkan untuk mengurangi penyebaran wabah virus corona (Ihsanuddin \& Galih, 2020). Kebijakan tersebut menjadi awal pola pembelajaran dari rumah mulai yang kemudian lebih ditegaskan lagi oleh Menteri pendidikan dengan mengeluarkan Surat Edaran Nomor: 36962/MPK.A/HK/2020. Dalam surat edaran tersebut, Menteri Pendidikan meminta Pemerintah Daerah dan Pimpinan Perguruan Tinggi memastikan bahwa bekerja dari rumah tidak mempengaruhi ukuran penilaian kinerja maupun sistem insentif yang diterima pendidik maupun tenaga kependidikan. Kemudian lebih lanjut dikatakan bahwa kehadiran fisik tidak menjadi ukuran kinerja, yang terpenting adalah pembelajaran tetap berjalan dan terus terjadi (Prodjo, 2020). Hal tersebut mendorong kepada para pelaku pendidikan untuk mulai beradaptasi dengan pembelajaran daring atau study from home.

Belajar dari rumah atau study from home merupakan langkah yang tepat dan yang harus dapat dilakukan oleh setiap sekolah di Indonesia, baik itu di jenjang pendidikan dasar, menengah ataupun pendidikan tinggi. Study from home tentunya menuntut kemampuan dari para pengajar untuk dapat menguasai teknologi untuk bisa melaksanakan study from home dengan baik. Kemampuan tersebut yakni pengelolaan dan pelaksanaan pembelajaran berbasis melalui media online atau daring (Sumanto \& Sadewo, 2021). Lebih lanjut, disampaikan bahwa salah satu hal yang harus dilakukan adalah pembelajaran daring supaya kegiatan belajar tetap 
berjalan (Handarini \& Wulandari, 2020). Penggunaan virtual learning dalam proses pembelajaran jarak jauh diyakini memberikan lebih kemudahan belajar, dapat berkomunikasi secara langsung sehingga materi mudah untuk diterima (Lestari, 2020). Sehingga dapat ditekankan bahwa pelaksanaan study from home tersebut dilakukan secara daring yang dapat diakses oleh peserta didik, sehingga proses belajar mengajar secara virtual bisa terjadi.

Menyimak hal tersebut, ditemukan sebuah permasalahan mengenai ketidaksiapan para guru dalam melaksanakan study from home pada salah satu sekolah dasar di kabupaten Bengkayang Kalimantan Barat. Kabupaten Bengkayang sendiri merupakan daerah yang berada pada perbatasan negara Republik Indonesia dan Malaysia (Dimmera \& Purnasari, 2020). Melalui hasil pengamatan yang dilakukan di Sekolah Dasar Negeri 02 Bengkayang, didapatkan tidak semua guru siap dalam melaksanakan pembelajaran melalui media daring. Hal tersebut karena beberapa guru di SDN 02 Bengkayang tidak sepenuhnya menguasai pembelajaran berbasis daring. Selain ketidaksiapan beberapa guru dalam pembelajaran berbasis daring, SDN 02 Bengkayang juga dihadapkan dengan permasalahan ketidaksiapan pengemasan materi dalam pembelajaran berbasis daring atau secara jarak jauh. Selain permasalahan ketidaksiapan dalam menjalankan pembelajaran secara daring atau jarak jauh, diungkapkan juga oleh beberapa guru SDN 02 Bengkayang bahwa terdapat kesusahan dalam memberi materi pembelajaran di bidang matematika. Selama pandemi berlangsung, salah satu guru yang mengampu mata pelajaran matematika mengungkapkan kesusahan dalam memberikan materi penjumlahan kepada murid didiknya yang sedang menempuh materi pelajaran penjumlahan. Hal tersebut tentunya memang benar susah, dikarenakan konsep pengajaran matematika dalam materi penjumlahan akan mudah dipahami oleh siswa ketika terjadi interaksi secara langsung, serta akan sangat mudah juga bagi guru bila mengajarkan konsep penjumlahan secara langsung. Di samping itu, guru juga akan mudah dalam mengamati kemampuan siswa dalam pemahaman mengenai konsep berhitung.

Sehingga kenyataan yang terjadi, guru sangat tergantung kepada LKS (lembar kerja siswa) serta guru hanya dapat memberikan tugas, mengoreksi hasil pekerjaan murid tanpa guru ketahui kemampuan sebenarnya dari murid didiknya dalam memahami penjumlahan. Fakta di lapangan selama pembelajaran secara daring/jarak jauh, guru tidak dapat memastikan bahwa apakah tugas siswa benar sepenuhnya hasil kerja siswa tersebut sendiri atau bukan. Guru juga sangat mengkhawatirkan kondisi siswa yang mungkin gagal dalam memahami konsep penjumlahan. Dilema dan kebingungan terjadi karena guru ingin mengharapkan siswa didiknya dapat memahami konsep penjumlahan dengan benar, tetapi guru tidak dapat memberikan materi penjumlahan dengan maksimal dikarenakan kebijakan pembelajaran daring/jarak jauh, serta di satu sisi kondisi pandemi Covid-19 sangatlah berbahaya yang menuntut guru harus kreatif dalam mengemas materi pembelajaran supaya dapat tersampaikan dengan baik kepada peserta didiknya. Salah satu bentuk yang dapat guru lakukan adalah dengan mengembangkan media pembelajaran yang dapat diakses oleh peserta didiknya yang bermanfaat untuk membantu belajar peserta didik dalam mata pelajaran matematika. Kendala yang dihadapi beberapa guru khususnya di SDN 02 Bengkayang tersebut senada dengan hasil temuan penelitian Sugiyono, S mengenai Problematik Pembelajaran Daring di Sekolah Dasar (Sugiyono, 2020). Disampaikan bahwa Transisi metode pembelajaran tersebut memunculkan banyak hambatan baik bagi guru, siswa, bahkan orang tua. Bagi guru sekolah dasar yang terbiasa melakukan pembelajaran secara tatap muka, kondisi ini memunculkan ketidaksiapan persiapan pembelajaran. Perubahan yang terjadi secara cepat dan mendadak sebagai akibat penyebaran Covid-19 membuat semua orang dipaksa untuk melek teknologi. Hal senada juga disampaikan oleh Al Ihwanah (2020), bahwa permasalahan dalam pelaksanaan pembelajaran daring tersebut antara lain ketidaksiapan sebagian guru dan sekolah, pemahaman sebagian guru yang keliru, ketidaksiapan orang tua/wali murid dalam membantu anak belajar daring, belajar daring membuat anak malas dan jenuh, pembelajaran daring kurang efektif untuk materi tipe praktikum, pembelajaran daring memerlukan modal dan jaringan internet yang cukup (Ihwanah, 2020). Permasalahan ketidaksiapan guru dan bagaimana pengemasan materi dalam media pembelajaran daring di SDN 02 Bengkayang menjadi salah satu perwakilan dari beberapa SD lainnya dalam menghadapi pembelajaran daring.

Berangkat dari hal tersebut, maka diperlukan sebuah solusi untuk membantu mengatasi kondisi penyampaian materi pembelajaran materi penjumlahan bilangan yang dihadapi guru dan siswa kelas I di SDN 02 Bengkayang. Solusi tersebut yakni dengan membuat video pembelajaran yang interaktif dengan menggunakan model pengembangan ADDIE, yaitu analysis, design, development, implementation, evaluation (Bakhri, 2019). Penggunaan model ADDIE dimaksudkan agar pembuatan video pembelajaran interaktif tersebut dikembangkan sesuai dengan sasaran, kebutuhan dan dapat digunakan oleh guru serta murid kelas I SDN 02 Bengkayang. Video pembelajaran interaktif juga dibuat berorientasi kepada kebudayaan lokal, agar video tersebut dapat lebih membuat antusias murid kelas I SDN 02 Bengkayang dalam melihat, menyimak video pembelajaran dalam materi penjumlahan bilangan.

Video pembelajaran berbasis kebudayaan lokal merupakan media pembelajaran yang dapat menunjang proses pembelajaran di kelas, terutama di tingkat sekolah dasar (Hasanah, Santoso, \& Furaidah, 2020). Diketahui juga bahwa media pembelajaran mampu membantu guru dalam menyajikan pembelajaran yang sesuai dengan 
perkembangan kognitif anak (Nurrita, 2018). Berdasarkan teori perkembangan kognitif Jean Piaget (Ibda, 2015), perkembangan kognitif siswa SD berada pada tahap operasional konkret. Objek konkret adalah objek yang dapat di indra oleh siswa, baik itu indra penglihat, indra peraba, indra pendengar, pengecap maupun pencium. Dalam hal ini, objek konkret tersebut terwujud dalam bentuk sebuah media pembelajaran.

Sedangkan kebudayaan lokal yang akan disisipkan dalam video pembelajaran tersebut adalah mengenai nilai-nilai budaya yang ada di Kabupaten Bengkayang. Seperti diketahui bersama, bahwa Bangsa Indonesia memiliki warisan budaya yang beragam di setiap daerahnya salah satunya di Kabupaten Tanah Datar yang memiliki kearifan budaya lokal sebagai ciri khas atau identitas budaya masyarakatnya. Kebudayaan atau kearifan lokal meliputi: bentuk catatan tertulis, karyakarya arsitektur/bangunan tradisional, benda cagar budaya, karya seni/kerajinan tangan tradisional, petuahpetuah yang di sampaikan secara verbal dan turuntemurun (Suryana \& Hijriani, 2021). Lebih lanjut disampaikan bahwa kebudayaan atau kearifan lokal merupakan nilai-nilai yang ada dan berlaku serta yang diyakini suatu kebenarannya dalam suatu masyarakat. Pengembangan media video pembelajaran berbasis kebudayaan lokal pada siswa sekolah dasar merupakan salah satu cara melestarikan kebudayaan lokal masyarakat setempat sejak dini. Salah satu kebudayaan atau kearifan lokal yang perlu dilestarikan adalah burung enggang sebagai burung endemik khas Kalimantan secara umum dan juga khas masyarakat Bengkayang secara khusus. Rangkong badak, Enggang (Buceros rhinoceros), Rangkong gading atau Tanghulu (Buceros vigil) merupakan binatang yang dilindungi di daerah Kalimantan (Pranoto, Pratiswa, \& Undiana, 2020). Burung Enggang dilindungi karena habitat dan populasinya dari tahun ke tahun semakin berkurang. Berkurangnya populasi burung yang dilindungi ini dikarenakan banyaknya perburuan paruh burung enggang dan perusakan hutan oleh pihak yang tidak bertanggung jawab (Aksad, 2018). Sehingga sudah menjadi hal yang wajib bagi para pendidik untuk memberitahukan hal tersebut kepada siswa sejak pendidikan dasar, supaya siswa ikut turut dalam mencintai kebudayaan lokal dan melestarikannya. Selain Burung Enggang, nilai kebudayaan lokal yang diambil adalah kekayaan demografi kabupaten Bengkayang, yakni adanya riam (air terjun) yang masih lestari dan asri.

Dipilihnya fokus solusi pembuatan video pembelajaran berorientasi kebudayaan lokal dikarenakan melalui video pembelajaran dapat diakses, ditonton dan didengar siswa yang akan sangat efektif dalam proses penyampaian materi pelajaran yang disampaikan oleh beberapa guru SDN 02 Bengkayang. Video pembelajaran berbasis kebudayaan lokal juga dapat digunakan dalam membantu siswa belajar penjumlahan bilangan, sehingga diharapkan dapat membantu peningkatan hasil belajar siswa. Hal tersebut sesuai dan sejalan dengan hasil penelitian yang telah dilakukan oleh (Busyaeri, Udin, \& Zaenudin, 2016), melalui judul penelitian yang dilakukannya yakni "Pengaruh penggunaan video pembelajaran terhadap peningkatan hasil belajar mata pelajaran IPA di MIN Kroya Cirebon". Hasil penelitian tersebut di mana disampaikan dalam hasil penelitiannya bahwa berdasarkan perhitungan data yang dihubungkan dengan angka indeks korelasi $(r)$ product moment yakni berada diantara 0,800-1 yang berarti dalam kategori korelasi yang sangat tinggi, sedangkan hasil perhitungan korelasi antara penggunaan video dengan hasil belajar siswa adalah 1,03 yang berarti memiliki hubungan yang sangat tinggi. Lebih lanjut menurut hasil penelitian yang telah dilakukan oleh (Supryadi, Jampel, \& Riastini, 2013) melalui judul penelitiannya yaitu "penerapan media video pembelajaran sebagai aplikasi pendekatan contextual teaching learning untuk meningkatkan hasil belajar IPA siswa kelas V". Dari Hasil penelitian yang dilakukan tersebut menunjukkan bahwa terjadi peningkatan hasil belajar IPA sebesar $67,9 \%$ (kategori sedang) pada siklus I, kemudian meningkat menjadi $82,8 \%$ pada siklus II (kategori tinggi). Ini menunjukkan bahwa terjadi peningkatan hasil belajar sebesar 14,9\% dari siklus I ke siklus II. Melalui hal tersebut, maka dapat disimpulkan bahwa melalui penerapan video pembelajaran sebagai aplikasi pendekatan contextual teaching learning dapat meningkatkan hasil belajar siswa kelas V SDN No. 2 Bengkel, Kecamatan Busungbiu, Kabupaten Buleleng. Dari dua hasil penelitian di atas maka dapat ditarik sebuah kesimpulan bahwa video pembelajaran dapat meningkatkan hasil belajar siswa. Hasil penelitian tersebut juga dapat memberikan gambaran bahwa dengan adanya atau dilakukannya pengembangan video pembelajaran matematika, akan dapat membantu siswa dalam memahami materi penjumlahan di mata pelajaran matematika, dan dapat di asumsikan dapat meningkatkan hasil belajar siswa di materi penjumlahan mata pelajaran matematika.

Berdasarkan fakta dan pemaparan yang telah disebutkan, maka melalui pengembangan video pembelajaran matematika berorientasi pada kebudayaan lokal diharapkan dapat membantu guru dan siswa SDN 02 Bengkayang dalam melaksanakan pembelajaran secara daring/jarak jauh serta dapat membantu siswa dalam memahami materi penjumlahan bilangan. Upaya pengembangan video pembelajaran tersebut tentunya dengan harapan pembelajaran yang dirancang tetap berjalan selama pandemi Covid-19 dengan tetap mengutamakan kesehatan dan keselamatan para siswa serta terjadi peningkatan keterampilan dalam membuat dan mengelola media pembelajaran bagi guru-guru SDN 02 Bengkayang dalam hal penyampaian materi dengan baik sehingga peserta didik dapat memahami materi. Video pembelajaran yang dikembangkan juga dapat digunakan sebagai media pembelajaran siswa saat berada di rumah dan dapat dilihat kapan pun ajaran. 


\section{RUANG LINGKUP}

Sejalan dengan latar belakang yang telah dipaparkan di atas, maka ruang lingkup dari penelitian ini adalah mengacu dari tujuan penelitian yang telah disusun, yakni:

1. Untuk mengetahui hasil pengembangan dari Video Pembelajaran Matematika Berorientasi Kebudayaan Lokal di SDN 02 Bengkayang.

2. Untuk mengetahui karakteristik pengembangan dari Video Pembelajaran Matematika Berorientasi Kebudayaan Lokal di SDN 02 Bengkayang.

\section{BAHAN DAN METODE}

Penelitian ini dikategorikan dalam jenis penelitian pengembangan (research and development), yaitu pengembangan Video Pembelajaran Matematika Berorientasi Kebudayaan Lokal. Model pengembangan yang digunakan dalam penelitian ini adalah model pengembangan dari Borg and Gall (Borg, 2003). Model pengembangan Borg and Gall terdiri dari 10 langkah yang kemudian dikelompokkan menjadi 3 langkah utama untuk memudahkan penelitian. Adapun langkah-langkah pengembangan dalam penelitian ini meliputi studi pendahuluan, pengembangan produk, dan validasi produk dan uji coba produk. Langkah tersebut juga dikombinasikan dengan model ADDIE yakni meliputi: analysis, design, development, implementation, evaluation.

Pada studi pendahuluan, langkah yang dilakukan yakni mengumpulkan dan menganalisis informasi mengenai permasalahan serta kebutuhan yang diperlukan dalam materi penjumlahan di mata pelajaran matematika, mengkaji dan merumuskan pentingnya video pembelajaran, mengkaji teori yang menjadi dasar pengembangan, serta mengkaji karakteristik video pembelajaran terdahulu. Selain itu pada tahap ini juga dilakukan identifikasi terhadap karakteristik guru dan siswa dalam hal penggunaan video pembelajaran, serta analisis materi yakni mengidentifikasi, merinci serta menyusun konsep secara sistematis hal ini dilakukan untuk pengorganisasian materi, dan tampilan video pembelajaran. Setelah langkah tersebut dilakukan maka tahap berikutnya adalah merancang komponenkomponen pendukung.

Tahap pengembangan produk disiapkan draft desain produk yang dikembangkan yakni Video Pembelajaran Matematika Berorientasi Kebudayaan Lokal. Sebelum diuji coba, draft produk dikaji kembali apakah kecukupan teori-teori pendukung produk telah dipenuhi dengan baik pada setiap komponen-komponen produk sehingga siap diuji secara valid oleh para ahli dan praktisi dari sudut rasional teoretis dan kekonsistenan konstruksi nya.

Pada tahapan validasi produk, akan dilakukan kegiatan validasi ahli. Kegiatan validasi dilakukan untuk menilai kelayakan dan kesahihan Video Pembelajaran Matematika Berorientasi Kebudayaan Lokal yang dikembangkan. Hasil validasi digunakan untuk merevisi
Video Pembelajaran Matematika Berorientasi Kebudayaan Lokal, sekaligus menunjukkan kelayakan Video Pembelajaran Matematika Berorientasi Kebudayaan Lokal yang akan digunakan guru dan siswa di SDN 02 Bengkayang. Kegiatan yang dilakukan pada waktu melakukan validasi model adalah sebagai berikut:

1. Meminta pertimbangan ahli dan praktisi tentang kelayakan Video Pembelajaran Matematika Berorientasi Kebudayaan Lokal, pada kegiatan ini diperlukan instrumen berupa lembar validasi yang diserahkan kepada validator.

2. Melakukan analisis terhadap hasil validasi dari validator. Jika hasil analisis menunjukkan:

1) Valid tanpa revisi, maka kegiatan selanjutnya adalah uji coba lapangan.

2) Valid dengan sedikit revisi, maka kegiatan selanjutnya adalah merevisi terlebih dahulu, kemudian langsung uji coba lapangan.

3) Tidak valid, maka dilakukan revisi sehingga diperoleh prototipe baru. Kemudian kembali pada kegiatan meminta pertimbangan ahli dan praktisi atau tahap validasi.

Setelah diperoleh produk yang valid maka, Video Pembelajaran Matematika Berorientasi Kebudayaan Lokal yang dikembangkan siap diuji coba. Pada saat proses uji coba atau implementation produk, dilakukan juga penyebaran lembar observasi untuk melihat/ menilai karakteristik video pembelajaran yang dikembangkan. Kemudian pada tahap evaluation, dilakukan kesimpulan dari kegiatan uji coba/implementation yang telah dilakukan serta menarik hasil dari lembar observasi yang disebar guna untuk mengetahui karakteristik dari produk video pembelajaran yang dikembangkan.

\subsection{Fokus Penelitian}

Fokus Penelitian dalam penelitian pengembangan ini adalah menghasilkan produk Video Pembelajaran Matematika Berorientasi Kebudayaan Lokal yang sesuai kebutuhan dan mempunyai karakteristik yang praktis yang dapat dengan mudah digunakan oleh guru dan siswa SDN 02 Bengkayang.

\subsection{Sumber Data}

Dalam penelitian ini, teknik yang digunakan untuk pengumpulan data yaitu, observasi (langsung) dilakukan untuk mengamati proses pengembangan dan uji coba produk, lembar validasi, digunakan sebagai instrument dalam uji coba, dan validasi produk yang dikembangkan, lembar Observasi yang diberikan kepada guru ataupun wali murid untuk meninjau respond siswa saat melihat video pembelajaran yang dikembangkan. Catatan lapangan yang dilakukan bersamaan dengan implementasi uji coba produk yang berisi tentang hal-hal yang terjadi selama berlangsungnya uji coba produk; Dokumentasi yang meliputi gambar atau foto selama berlangsungnya penelitian pengembangan (research and development) yang dilakukan. 


\subsection{Teknik Analisis Data}

Teknik analisis data yang akan digunakan dalam penelitian ini menggunakan analisis kuantitatif deskriptif untuk menganalisis lembar Observasi dan uji pakar yang dilakukan. Rentang nilai dan kriteria dari uji pakar mengacu pada Tabel 1.

Tabel 1. Kriteria Penilaian Uji Pakar

\begin{tabular}{|c|l|l|}
\hline Nilai & Rata-Rata Skor & $\begin{array}{l}\text { Indikator } \\
\text { Penilaian Validasi }\end{array}$ \\
\hline $10,00 \leq \bar{x} \leq 18,00$ & $1,0 \leq \bar{x} \leq 1,8$ & Tidak Baik \\
\hline $18,00<\bar{x} \leq 26,00$ & $1,8<\bar{x} \leq 2,6$ & Kurang Baik \\
\hline $26,00<\bar{x} \leq 34,00$ & $2,6<\bar{x} \leq 3,4$ & Cukup Baik \\
\hline $34,00<\bar{x} \leq 42,00$ & $3,4<\bar{x} \leq 4,2$ & Baik \\
\hline $42,00<\bar{x} \leq 50,00$ & $4,2<\bar{x} \leq 5,0$ & Sangat Baik \\
\hline
\end{tabular}

Kriteria penilaian dan rentang nilai yang ditunjukkan pada Tabel 1 digunakan sebagai pedoman pengambilan nilai terhadap uji pakar. Rentang nilai diperoleh berdasarkan perhitungan dengan melihat skor maksimal dan skor minimal yang diperoleh dan dibandingkan dengan banyaknya opsi jawaban. Penjabaran opsi jawaban dilakukan dengan menggunakan skala Likert termasuk dalam indikator penilaian validasi.

\section{PEMBahasan}

Media pembelajaran merupakan sarana pembelajaran yang akan memudahkan penyampaian materi ajar sehingga proses pembelajaran dapat berjalan dengan lebih efektif. Media pembelajaran juga berfungsi sebagai alat yang membantu guru sehingga guru dapat menyampaikan materi dengan lebih menyenangkan sekaligus mudah menarik minat dan perhatian siswa. Untuk itu diharapkan guru dapat menggunakan bahkan mengembangkan media sesuai dengan kebutuhan di kondisi kelas masing-masing. Menjawab kebutuhan tersebut, dengan berkolaborasi bersama guru kelas di SDN 2 Bengkayang, pengembangan media pembelajaran berbasis digital ini dibuat dan diukur manfaat dari pengembangan media ini. Adapun hasil dari pengembangan video pembelajaran sebagai media ajar dijabarkan secara rinci di bawah ini.

\section{Pengembangan Video Pembelajaran}

Media yang dikembangkan adalah berupa video pembelajaran berbasis kearifan lokal. Materi yang menjadi isi dari video adalah pembelajaran matematika dengan bahasan penjumlahan dua bilangan. Penyampaian materi yang terdapat dalam video berupa cerita pendek disertai dengan latihan operasi hitung penjumlahan. Pengembangan media ini menggunakan langkah dari Borg and Gall yang terdiri dari 3 tahapan utama yakni pendahuluan, pengembangan produk, dan validasi.

Tahap pendahuluan berupa kegiatan mengkaji kebutuhan media dalam pembelajaran di kelas 1 SDN 2 Bengkayang, kemudian diskusi dengan guru untuk menggali sejauh mana penerapan media berbasis digital, termasuk pembahasan mengenai kendala dan solusi yang dapat direncanakan untuk mengatasi kendala yang ada. Setelah dilakukan diskusi, maka disusun konsep isi dari video dan kembali didiskusikan bersama guru. Setelah disepakati konsep dari video yang dikembangkan, langkah selanjutnya adalah pembuatan video pembelajaran.

Tahap berikutnya adalah tahap validasi terhadap video yang dikembangkan. Validasi dilakukan dengan uji pakar yakni menilai kelayakan video pembelajaran. Pakar dalam validasi produk dipilih 6 orang dengan 3 kategori kelompok. Kelompok pertama yang terdiri dari 2 orang berasal dari dosen, kelompok ke dua terdiri dari guru, dan kelompok ke tiga terdiri dari orang tua. Terdapat 3 indikator dalam instrumen uji pakar yang meliputi komponen isi, komponen, tampilan, dan komponen aksesibilitas. Jabaran mengenai kisi-kisi pengembangan instrumen uji pakar ditunjukkan pada Tabel 2.

Tabel 2. Kisi-Kisi Lembar Uji Pakar

\begin{tabular}{|l|l|ll|}
\hline No & Indikator & Sub Indikator & \\
\hline 1. & Komponen & $\begin{array}{l}\text { - Kesesuaian } \\
\text { kompetensi dengan } \\
\text { dalam video materi }\end{array}$ \\
& Isi & $\begin{array}{l}\text { - Kesesuaian materi dengan } \\
\text { perkembangan peserta didik } \\
\text { dan norma } \\
\text { - Kesesuaian tata bahasa dengan } \\
\text { perkembangan peserta didik } \\
\text { - Menampilkan unsur kearifan } \\
\text { lokal }\end{array}$ \\
\hline 2. & $\begin{array}{l}\text { Komponen } \\
\text { Tampilan }\end{array}$ & $\begin{array}{l}\text { - Tampilan menarik } \\
\text { - Konsep animasi sesuai dengan } \\
\text { perkembangan peserta didik }\end{array}$ \\
\hline 3. & $\begin{array}{l}\text { Komponen } \\
\text { Aksesibilitas }\end{array}$ & $\begin{array}{l}\text { - Akses daring } \\
\text { - Akses luring } \\
\text { - Perangkat pendukung }\end{array}$ \\
\hline
\end{tabular}

Selanjutnya, masing-masing uji pakar diberikan instrumen dan diberikan video pembelajaran yang telah dibuat untuk dapat dilakukan penilaian. Adapun hasil uji pakar ditampilkan pada Tabel 3.

Tabel 3. Penilaian Uji Pakar

\begin{tabular}{|l|l|l|l|}
\hline No & Pakar & Skor & Indikator \\
\hline 1 & Dosen_1 & 36 & Baik \\
\hline 2 & Dosen_2 & 34 & Cukup Baik \\
\hline 3 & Guru_1 & 45 & Sangat Baik \\
\hline 4 & Guru_2 & 43 & Sangat Baik \\
\hline 5 & Orgtua_1 & 48 & Sangat Baik \\
\hline 6 & Orgtua_2 & 44 & Sangat Baik \\
\hline \multicolumn{2}{|l}{ Rata-Rata } & 41.67 & Baik \\
\hline
\end{tabular}

Berdasarkan penilaian yang diberikan dalam uji pakar, diketahui bahwa nilai rata-rata mencapai 41,67 dengan kategori Baik. Perolehan nilai ini menunjukkan bahwa media yang dikembangkan layak untuk digunakan atau diuji coba. Meskipun skor yang diberikan secara 
keseluruhan menunjukkan hasil yang memuaskan, namun dari Pakar dalam kelompok Dosen terdapat beberapa masukan yakni berupa penambahan subtitle dan pemilihan warna dalam video dapat lebih diperhatikan lagi. Berdasarkan masukkan tersebut maka dilakukan perbaikan terhadap kualitas isi video. Tampilan video yang telah di unggah pada media YouTube ditunjukkan pada Gambar 1.

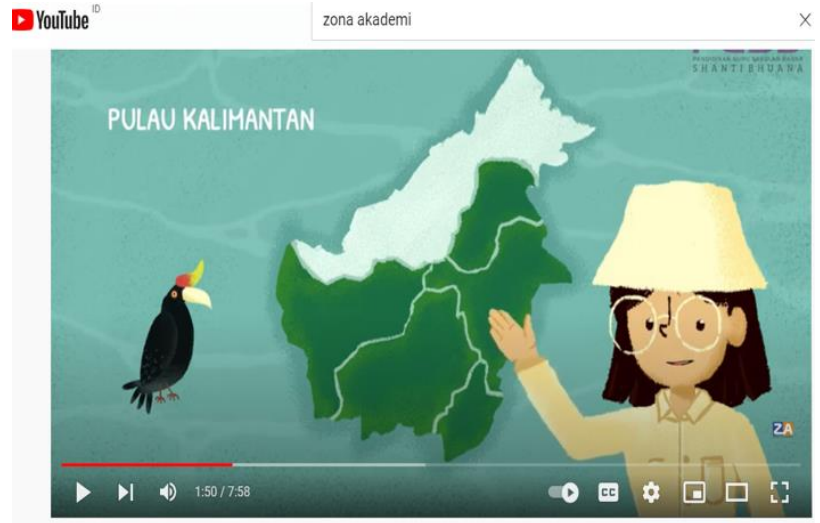

VIDEO ANIMASI PEMBELAJARAN ANAK SD - MATERI PENJUMLLAHAN DUA BILANGAN_PGSD ISB 133 views $\cdot$ Jul 15,202

$$
\text { 16 } 21 \text { DISLIKE } \leadsto \text { SHARE } \equiv+\text { SAVE } \ldots
$$

Zona Akademi
257 subscribers

SUBSCRIBED

\section{Gambar 1. Tampilan Video Pembelajaran di YouTube}

Video pembelajaran yang dikembangkan juga telah $d$ unggah di YouTube sebagaimana ditampilkan pada Gambar 1, hal ini bertujuan agar video pembelajaran dapat diakses secara daring dan sekaligus menjadi sarana untuk penyebarluasan produk. Selanjutnya terhadap video yang telah terunggah, maka dilanjutkan pada tahap implementasi produk untuk menilai karakteristik dari video pembelajaran yang dikembangkan. Video pembelajaran juga telah menampilkan unsur kebudayaan lokal berupa burung enggang dan riam (air terjun).

2. Karakteristik pengembangan video pembelajaran

Pengukuran terhadap karakteristik produk dilakukan dengan menyebarkan lembar observasi kepada guru dan orang tua untuk mengukur respond peserta didik terhadap video pembelajaran yang dikembangkan. Pada tahap ini, pengisian angket dilakukan oleh orang tua maupun guru mengingat siswa kelas 1 SD belum dapat mengisi lembar observasi secara mandiri. Kisi-Kisi Lembar Observasi disajikan pada Tabel 4.
Tabel 4. Kisi-Kisi Lembar Observasi

\begin{tabular}{|l|l|l|}
\hline No & Indikator & Sub Indikator \\
\hline 1. & $\begin{array}{l}\text { Keaktifan } \\
\text { peserta didik }\end{array}$ & $\begin{array}{l}\bullet \text { Kemampuan bertanya } \\
\text { Kemampuan memberikan } \\
\text { tanggapan }\end{array}$ \\
\hline 2. & $\begin{array}{l}\text { Minat peserta } \\
\text { didik }\end{array}$ & $\begin{array}{l}\text { - Antusiasme peserta didik } \\
\bullet \text { Ketertarikan }\end{array}$ \\
\hline 3. & Pemahaman & $\begin{array}{l}\bullet \text { Kemampuan memahami materi } \\
\text { Kemampuan mengenal unsur } \\
\text { budaya }\end{array}$ \\
\hline
\end{tabular}

Kisi-kisi pada tabel 4, selanjutnya dikembangkan menjadi lembar observasi yang digunakan untuk mengetahui respond siswa setelah melihat video pembelajaran sehingga dapat diketahui karakteristik video pembelajaran yang dikembangkan. Adapun hasil dari analisis lembar observasi dijabarkan pada Tabel 5.

Tabel 5. Hasil Analisis Lembar Observasi

\begin{tabular}{|c|c|c|c|}
\hline No & Kode Responden & Skor & Kategori \\
\hline 1 & RSP_1 & 87.5 & Sangat Baik \\
\hline 2 & RSP_2 & 75 & Baik \\
\hline 3 & RSP_3 & 62.5 & Cukup \\
\hline 4 & RSP_4 & 100 & Sangat Baik \\
\hline 5 & RSP_5 & 75 & Baik \\
\hline 6 & RSP_6 & 62.5 & Cukup \\
\hline 7 & RSP_7 & 100 & Sangat Baik \\
\hline 8 & RSP_8 & 62.5 & Cukup \\
\hline 9 & RSP_9 & 87.5 & Sangat Baik \\
\hline 10 & RSP_10 & 62.5 & Cukup \\
\hline 11 & RSP_11 & 75 & Baik \\
\hline 12 & RSP_12 & 62.5 & Cukup \\
\hline 13 & RSP_13 & 100 & Sangat Baik \\
\hline 14 & RSP_14 & 62.5 & Cukup \\
\hline 15 & RSP_15 & 62.5 & Cukup \\
\hline 16 & RSP_16 & 87.5 & Sangat Baik \\
\hline 17 & RSP_17 & 62.5 & Cukup \\
\hline 18 & RSP_18 & 100 & Sangat Baik \\
\hline 19 & RSP_19 & 75 & Baik \\
\hline 20 & RSP_20 & 62.5 & Cukup \\
\hline 21 & RSP_21 & 100 & Sangat Baik \\
\hline 22 & RSP_22 & 75 & Baik \\
\hline 23 & RSP_23 & 87.5 & Sangat Baik \\
\hline 24 & RSP_24 & 87.5 & Sangat Baik \\
\hline 25 & RSP_25 & 62.5 & Cukup \\
\hline 26 & RSP_26 & 87.5 & Sangat Baik \\
\hline 27 & RSP_27 & 100 & Sangat Baik \\
\hline 28 & RSP_28 & 100 & Sangat Baik \\
\hline \multicolumn{2}{|c|}{ Rata-Rata } & 77.2 & Baik \\
\hline
\end{tabular}

Berdasarkan analisis berupa hasil analisis lembar observasi, maka dapat diketahui bahwa rata-rata skor menunjukkan hasil yang baik yakni dengan nilai 77,2 dengan kategori Baik. Hal ini menunjukkan bahwa respond siswa setelah melihat video pembelajaran yang dikembangkan adalah positif, siswa merasa senang dan dapat memahami apa yang diputarkan dalam video pembelajaran. Hal ini juga berarti bahwa video yang dikembangkan sesuai dengan tingkat perkembangan siswa, serta isi dari video tersebut dapat dimengerti oleh 
siswa. Persentase respond siswa terhadap video pembelajaran ditunjukkan pada Gambar 2.

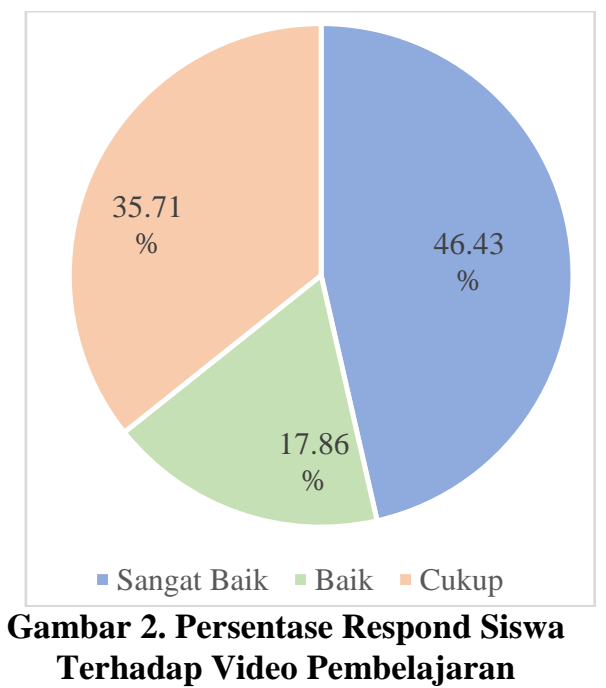

Berdasarkan persentase yang ditunjukkan pada Gambar 2, dapat diketahui bahwa sebagian besar siswa yakni $46,43 \%$ memberikan respond yang sangat baik. Tidak ada siswa yang memberikan respond kurang ataupun sangat kurang. Dengan demikian dapat ditarik kesimpulan bahwa video pembelajaran berbasis kebudayaan lokal yang dikembangkan memiliki karakteristik yakni mudah dipahami siswa, menarik minat dan antusiasme siswa dalam pembelajaran, serta dapat membantu siswa saat belajar di rumah.

Hasil yang ditemukan tersebut juga mendukung penelitian yang dilakukan oleh Putri, dkk (2020) melalui penelitian yang dilakukannya yakni Pengembangan Video Edukasi Kartun Animasi Materi Siklus Air untuk Memfasilitasi Siswa Sekolah Dasar. Hasil penelitian tersebut menjelaskan bahwa berdasarkan hasil uji ahli, media video edukasi kartun animasi valid atau layak dimanfaatkan dan digunakan dalam pembelajaran. Disampaikan juga bahwa media video edukasi dengan inovasi kartun animasi menjadi salah satu alternatif media yang dapat membantu guru sebagai media yang modern dan mampu menarik perhatian siswa dalam proses pembelajaran. Hal tersebut menunjukkan bahwa siswa lebih tertarik menggunakan inovasi media video edukasi daripada hanya menggunakan buku teks (Putri, Kuswandi, \& Susilaningsih, 2020).

Hasil penelitian yang didapat juga mendukung temuan dari Putu Darma Wisada, dkk (2019) dengan penelitian yang dilakukannya yakni Pengembangan Media Video Pembelajaran Berorientasi Pendidikan Karakter. Hasil penelitian tersebut menegaskan bahwa pengembangan media video pembelajaran berorientasi pendidikan karakter sangat efektif dalam membantu peningkatan kemampuan siswa (Wisada, Sudarma, \& Yuda, 2019).

Pengembangan video pembelajaran matematika berbasis kebudayaan lokal pada materi penjumlahan dua bilangan pada siswa kelas I SDN 02 Bengkayang yang dilakukan mendapatkan nilai baik berdasarkan nilai tim ahli dan layak untuk diuji coba. Produk tersebut juga mempunyai karakteristik yang mudah dipahami siswa, menarik minat dan antusiasme siswa dalam pembelajaran, serta dapat membantu siswa saat belajar di rumah. Pengembangan video pembelajaran tersebut tidak sampai kepada proses uji efektifitas produk dalam hasil belajar, hal tersebut dikarenakan hambatan dan kendala dalam pembelajaran daring, lokasi, serta kondisi pandemi covid-19 yang terjadi.

\section{KESIMPULAN}

Secara garis besar video pembelajaran yang dikembangkan telah berada pada kategori valid dan layak untuk diimplementasikan. Hal ini ditunjukkan dengan hasil penilaian uji pakar yang mendapat nilai rata-rata 41,67 di mana kategori dari nilai tersebut adalah baik. Pengukuran karakteristik video dilakukan dengan menggunakan lembar observasi dengan nilai rata-rata sebesar 77,2 dengan kategori baik. Persentase dari penilaian lembar observasi menunjukkan nilai sebesar $46,43 \%$ siswa memberikan respond yang sangat baik, $17,86 \%$ siswa memberikan respond yang baik, dan $35,71 \%$ siswa memberikan respond cukup. Hasil ini mengindikasikan bahwa video pembelajaran yang dikembangkan memiliki karakteristik yakni mudah dipahami siswa, menarik minat dan antusiasme siswa dalam pembelajaran, serta dapat membantu siswa saat belajar di rumah.

\section{SARAN}

Peneliti yang tertarik dengan topik serupa dapat melakukan penelitian dengan menggunakan metode pengembangan ataupun mix method dengan fokus menelaah kedudukan video pembelajaran terhadap capaian pembelajaran yang dapat ditinjau dari karakteristik peserta didik sehingga menghasilkan temuan yang memberikan kontribusi dalam perkembangan ilmu pendidikan.

\section{DAFTAR PUSTAKA}

Aksad, H. (2018). Rancang Bangun Game Adventure Burung Enggang Berbasis Android Menggunakan Scirra Construct 2. Progresif: Jurnal Ilmiah Komputer, 13(2).

Bakhri, S. (2019). Animasi interaktif pembelajaran huruf dan angka menggunakan model ADDIE. INTENSIF: Jurnal Ilmiah Penelitian Dan Penerapan Teknologi Sistem Informasi 3, no. 2 , 130-144.

Borg, W. R. (2003). Educational Research: an Introduction (7. ed). New York: Logman Inc.

Busyaeri, Udin, A. T., \& Zaenudin, A. (2016). Pengaruh penggunaan video pembelajaran terhadap peningkatan hasil belajar mapel IPA di MIN Kroya Cirebon. Al Ibtida: Jurnal Pendidikan Guru MI, 3(1). 
Dimmera, B. G., \& Purnasari, P. D. (2020). Permasalahan dan Solusi Program Indonesia Pintar dalam Mewujudkan Pemerataan Pendidikan di Kabupaten Bengkayang . Sebatik, 24(2), 307-314.

Handarini, O. I., \& Wulandari, S. S. (2020). Pembelajaran daring sebagai upaya study from home (SFH) selama pandemi covid 19. Jurnal Pendidikan Administrasi Perkantoran (JPAP), 8 (3), 496-503.

Hasanah, S. A., Santoso, A., \& Furaidah. (2020). Pengembangan Multimedia Interaktif Berbasis Kebudayaan Lokal pada Tema Indahnya Kebersamaan untuk Siswa Kelas IV. Jurnal Pendidikan: Teori, Penelitian, dan Pengembangan, 5(10), 1485-1494.

Ibda, F. (2015). Perkembangan kognitif: teori jean piaget. Intelektualita, 3(1).

Ihsanuddin, \& Galih, B. (2020, Maret 16). Kompas.com. Retrieved from Kompas.com: https://nasional.kompas.com/read/2020/03/16/1 5454571/jokowi-kerja-dari-rumah-belajar-darirumah-ibadah-di-rumah-perlu-digencarkan

Ihwanah, A. (2020). Problematika Pembelajaran Daring Di Sekolah Dasar Pada Era Pandemi Covid-19. JIEES: Journal of Islamic Education at Elementary School, 1(2), 44-51.

Lestari, S. W. (2020). Kendala Pelaksanaan Pembelajaran Jarak Jauh (PJJ) Dalam Masa Pandemi Ditinjau Dari Media Pembelajar. Jurnal Ilmu Pendidikan. Volume 2 No. 3.

Nurrita, T. (2018). Pengembangan media pembelajaran untuk meningkatkan hasil belajar siswa. MISYKAT: Jurnal Ilmu-ilmu Al-Quran, Hadist, Syari'ah dan Tarbiyah, 3(1), 171-210.

Pranoto, I., Pratiswa, S. A., \& Undiana, N. N. (2020). Motif Burung Enggang Gading Pada Pakaian Adat Dayak Kanayatn Kalimantan Barat. Gorga: Jurnal Seni Rupa 9, no. 2, 226-231.

Prodjo, W. A. (2020, 03 20). Kompas.com. Retrieved from Kompas.com: https://www.kompas.com/edu/read/2020/03/20/ 173617371/belajar-dari-rumah-nadiem-mintadinas-pendidikan-dan-kampus-siapkanpedoman

Putri, A. I., Kuswandi, D., \& Susilaningsih. (2020). Pengembangan Video Edukasi Kartun Animasi Materi Siklus Air Untuk Memfasilitasi Siswa Sekolah Dasar. Jurnal Kajian Teknologi Pendidikan, 3(4), 377-387.

Sugiyono, S. (2020). Problematika Pembelajaran Daring di Sekolah Dasar. Pacitan: LPPM PRESS STKIP PGRI Pacitan, PACITAN. ISBN 978602-53557-6-9.

Sumanto, Y., \& Sadewo, Y. D. (2021). Pelatihan Pembuatan Video Pembelajaran sebagai Media Pembelajaran Daring di SD Negeri Sojopuro dalam Masa Covid-19. Journal of Educational Learning and Innovation (ELIa), 1(1), 01-14.

Supryadi, P. E., Jampel, I. N., \& Riastini, P. N. (2013). Penerapan media video pembelajaran sebagai aplikasi pendekatan contekstual teaching learning untuk meningkatkan hasil belajar IPA siswa kelas V. MIMBAR PGSD Undiksha, 1(1).

Suryana, D., \& Hijriani, A. (2021). Pengembangan Media Video Pembelajaran Tematik Anak Usia Dini 5-6 Tahun Berbasis Kearifan Lokal. Jurnal Obsesi: Jurnal Pendidikan Anak Usia Dini, 6(2), 1077-1094.

Wisada, P. D., Sudarma, I. K., \& Yuda, A. I. (2019). Pengembangan Media Video Pembelajaran Berorientasi Pendidikan Karakter. Journal of Education Technology, 3(3), 140-146.

\section{UCAPAN TERIMA KASIH}

Ucapan terima kasih diberikan kepada PRPM Institut Shanti Bhuana, Bengkayang Kalimantan Barat atas segala dukungannya. Ucapan terima kasih juga diberikan kepada Pascasarjana Teknologi Pendidikan Universitas

Negeri Jakarta untuk dukungan dan bimbingannya.

Ucapan terima kasih juga diberikan kepada SDN 02

Bengkayang atas kerja sama dan dukungannya dari awal penelitian hingga akhir penelitian dilakukan. 